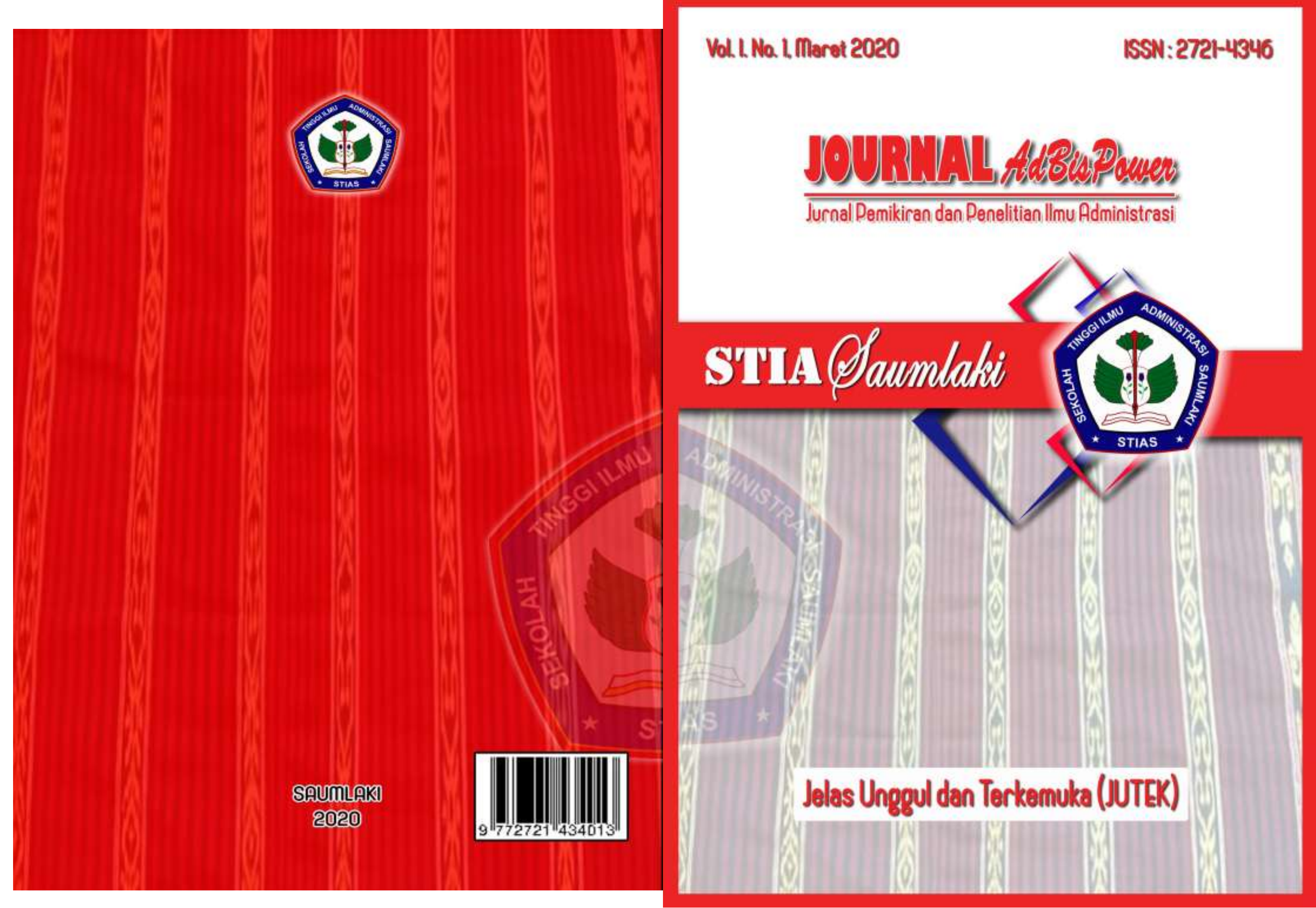




\title{
KEBIJAKAN PEMERINTAH DAERAH DALAM MENGALIHKAN JABATAN FUNGSIONAL KE JABATAN STRUKTURAL
}

Oleh:

\author{
Polikarpus Lalamafu \\ (Dosen STIASaumlaki)
}

\begin{abstract}
ABSTRAK
Penelitan ini bertujuan untuk mengetahui dan menganalisis Kebijakan Pemerintah Daerah dalam Mengalihkan Jabatan Fungsional ke Jabatan Struktural pada Kabupaten Maluku Tenggara Barat merupakan salah satu kebijakan yang mengabaikan kebutuhan masyarakat dan tidak sesuai dengn kondisi daerah serta tidak didasarkan pada pilihan rasional yang mempertimbangkan unsur prioritas kebutuhan. Metode yang digunakan dalam penelitian ini adalah pendekatan kualitatif dengan teknik analisis data Metode yang digunakan dalam penelitian ini ialah pendekatan kualitatif dengan teknik analisis data menggunakan model menggunakan Model Miles Dan Huberman, melalui prosedur Reduksi Data, Penyajian Data, dan Penarikan Kesimpulan.

Berdasarkan hasil penelitian yang dilakukan ditemukan adanya kebijakan pengalihan kekuasaan, masih terdapat ketidaksesuaian bidang keahlian serta latar belakang pendidikan dengan jabatan yang diembannya sehingga dalam pelaksanaan tugas jabatannya menjadi tidak efektif dan efisien.
\end{abstract}

Kata Kunci: Kebijakan dan Pengalihan Jabatan

\begin{abstract}
This research aims to identify and analyze Regional Government Policies in Transferring Functional Positions to Structural Positions in West Southeast Maluku Regency, which is one of the policies that ignores the needs of the community and is not in accordance with regional conditions and is not based on rational choices that consider elements of priority needs. The method used in this research is a qualitative approach with data analysis techniques. The method used in this study is a qualitative approach to data analysis techniques using a model using the Miles and Huberman Model, through the procedure of data reduction, data presentation, and conclusion drawing.

Based on the results of the research conducted, it was found that there was a policy of transferring power, there was still a mismatch between the fields of expertise and educational background with the positions they held so that the implementation of their duties became ineffective and efficient.
\end{abstract}

Keywords: Policy and Position Transfer 


\section{PENDAHULUAN}

Globalisasi yang terjadi sangat mempengaruhi segala bidang kehidupan manusia misalnya bidang pendidikan, kesehatan, teknologi dan lain sebagainya. Perubahan tersebut merambat dalam penyelenggaraan pemerintahan dimana reformasi dalam tubuh birokrasi terus dilakukan baik dari segi struktur, menajemen, kinerja, sampai pada perilaku birokrat. Birokrat dituntut untuk serius dan tanggap untuk memberikan pelayaan yang prima kepada masyarakat sesuai dengan asas transparansi, akuntabilitas, serta prinsip kemerataan, keadilan dan kejujuran untuk mewujudkan kesejahtraan. Reformasi tersebut kemudian semakin jelas dengan diberlakukannya Undang-undang No. 32 Tahun 2004 yang diperbaharui dengan Undang-undang No. 23 tahun 2014 tentang Pemerintahan Daerah yang didalamnya daerah diberikan hak, kewenangan dan kewajiban untuk mengatur dan mengurus sendiri urusan pemerintahan dan kepentingan masyarakat setempat serta pendapatan daerah yang merupakan hak daerah yang diakui dengan tetap berpegang pada prinsip demokrasi, peningkatan partisipasi aktif dari masyarakat, pemerataan dan keadilan, tanpa mengabaikan potensi dan keanekaragaman sebagi kekayaan daerah.

Dengan demikian daerah diberi kepercayaan untuk mengatur dan mengurus sendiri kebutuhan masyarakat karena daerah mengetahui prioritas kebutuhan dari masyarakatnya. Kebutuan masyarakat kemudian tertuang dalam bentuk kebijakan yang menghasilkan tindakan untuk dilaksanakan dan atau tidak dilaksanakan oleh pemerintah sehingga kebutuhan masyarakat dapat terpenuhi. Selain itu sebagai wujud orinetasi nilai dari sebuah kebijakan, maka kebijakan haruslah didasarkan pada pilihan yang rasional (rational choice) serta benar-benar diperuntuhkan bagi kebutuhan rakyat sehingga hasil akhir (outcome) yang diinginkan dapat tercapai dalam mewujudkan pemerintahan daerah yang efektif, efisien dan akuntabel.

Dalam merumuskan sebuah kebijakan masyarakat tidak lagi dipandang sebagai objek utama dari kebijakan tanpa mengabaikan aspek kepentingan bersama serta prinsip keadilan, yang dapat dinikmati oleh kelompok sasaran (target groups). Menurut James E. Anderson sebagaimana dikutip dalam Islamy (2009: 17) mengatakan bahwa kebijakan adalah "Serangkaian tindakan yang mempunyai 
tujuan untuk diikuti dan dilaksanakan oleh individu atau sekelompok pelaku guna memecahkan suatu masalah tertentu". Kebijakan memuat tindakan-tindakan nyata dan pilihan yang rasional manjadi syarat mutlak dari kebijakan baik pusat maupun daerah yang dalam perumusannya perlu dipertimbangkan konsekwensi yang akan terjadi sebagai akibat dari pelaksanaan kebijakan tersabut. Hal tersebut tidak saja dibahas oleh kalangan teoritis dan pemerhati, tetapi juga oleh para praktisi, bahkan telah menjadi isu publik (public issues) sehingga setiap orang tergerak untuk memikirkan dan mencari solusi atas masalah yang dihadapinya (Alaslan, 2021: 88)

Dalam hal ini pejabat birokrasi maupun pejabat politik memegang peran yang sama dalam menentukan kebijakan daerah kerena baik pejabat birokrasi maupun pejabat politik masing-masing memiliki kewenangan dalam menentukan sebuah kebijakan. Berdasarkan pertimbangan tersebut, maka secara jelas akan ada faktor pengaruh unsur politik yang masuk mempengaruhi pengambilan keputusan sebagai proses penentuan kebijakan. Wayne Parsons (2011:251). Oleh karena itu secara sederhana dapat dikatakan pembuatan keputusan sebagai proses penentuan kebijakan tidak terlepas dari pengaruh faktor politik.

Berdasarkan konsep di atas bukan berarti bahwa faktor politik menjadi alasan wajib, tetapi unsur analisis kebutuhan dan dampak dari kebijakan serta tahapantahapan yang didalamnya mempertimbangkan segala aspek sebelum diberlakukannya sebuah kebijakan. Namun proses ini diabaikan, sehingga tujuan kebijakan untuk mengatasi masalah justru menimbulkan masalah baru dengan dampak yang lebih tinggi dari kebijakan sebelumnya dan masyarakat selaku kelompok sasaran dari kebijakan menjadi korban kebijakan pemerintahanya sendiri.

Proses inilah yang kemudian dikatakan oleh Alaslan (2021: 3) sebagai kebijakan yang yang bersifat otoritatif karena kebijakan publik hanya dimaknai sebagai proses decision making yang cenderung membiarkan sesuatu itu terjadi, demi teratasinya suatu persoalan publik, terlibih khusus di Kabupaten Maluku Tenggara Barat.

Keterbatasan pejabat fungsional semakin meningkat tiap tahunnya, dan hal ini disebabkan karena pejabat fungsional tersebut dialihkan dalam jabatan struktural. Jumlah dokter yang dialihkan dalam jabatan struktur pada tahun 2013, 2014, dan 2015 
adalah 2, 0, dan 5 dokter di tahun terakhir dengan demikian terdapat 7 dokter yang dialihkan dalam jabatan struktural. Sedangkan jumlah guru yang dialihkan dalam jabatan struktural pada tahun yang sama ialah 14, 32, dan di tahun terakhir mencapai 73 guru sehingga jumlah guru yang dialihkan dalam jabatan struktural berjumlah 119 guru.

Kehadiran petugas kesehatan pada unit-unit pelayanan akan lebih membantu dibandingkan berdirinya bangunan tetapi kosong. Sedangkan di bidang pendidikan apa artinya sejumlah anggaran digulirkan sebagai stimulus dalam program pemberantasan buta huruf namun siapa yang akan mengajarkan murid untuk dapat membaca jika tenaga pengajar di sekolah kurang. Realitas ini membuktikan bahwa kebijakan pengalihan jabatan fungsional ke jabatan struktural pada Kabupaten Maluku Tenggara Barat merupakan salah satu kebijakan yang mengabaikan kebutuhan masyarakat dan tidak sesuai dengn kondisi daerah serta tidak didasarkan pada pilihan rasional yang mempertimbangkan unsur prioritas kebutuhan. Kenyataan lain juga ialah bahwa jika jabatan struktural terbatas maka dapat dialihkan dari jabatan fungsional akan tetapi konsekwensinya pada jabatan fungsional akan mengalami kekosongan dan tidak dapat diisi secara sembarangan dikarenakan jabatan fungsional merupakan jabatan keahlian.

Hal ini justru sangat urgen, apa yang terjadi jika pejabat dengan spesifikasi ilmu yang bukan didasarkan pada keahlian melakukan operasi, yang jelas itu tidak mungkin. Sesungguhnya terdapat banyak metode yang dapat digunakan sebagai alternatif pilihan untuk menentukan kebijakan dalam mengisi jabatan struktural, yakni melalui rekrutmen berdasarkan kualifikasi jabatan, peningkatan arus koordinasi intern dan ekstern pada dinas maupun badan daerah serta pemberdayaan aparatur pemerintahan lewat pendidikan dan pelatihan. Metode ini perlu dipertimbangkan secara konseptual, sehingga tidak perlu dilakukan pengalihfungsian untuk mengisi kekosongan pada jabatan struktural. Dengan demikian penelitian ini beujuan untuk mengetahui proses kebijakan pengalihan jabatan fungsional ke jabatan struktural di Kabupaten Maluku Tenggara Barat.

\section{LANDASAN TEORI}

\section{Konsep dan Proses Kebijakan Publik}

Kebijakan publik menurut Easton dikutip dalam Leo Agustino (2008: 6) merupakan pengalokasian nilai-nilai secara paksa bagi seluruh anggota masyarakat. Konsep lain diungkapkan oleh Woll, dikutip 
Tangkilisan

(2003:2)

mengatakan

bahwa"kebijakan

publik

merupakanpemecahan

masalah

$\mathrm{di}$

masyarakatyang dilakukan oleh pemerintah.

Berdasarkan defenisi tersebut maka secara sederhana kebijakan publik merupakan "pilihan tindakan" pemerintah untuk melakukan dan tidak melakukan sesuatu selain itu kebijakan publik dipandang sebagai tindakan pemerintah yangdilakukan dalam rangka merespon serta memecahkan masalah publik yang dihadapi.

Proses kebijakan publik merupakan proses yang panjang dan sangat kompleks hal ini juga ditegaskan oleh Suharno (2010: 52) yang mengatakan proses pembuatan kebijakan merupakan pekerjaan yang rumit dan kompleks dan tidak semudah yang dibayangkan, karena didalam melibatkan banyak proses maupun variabel yang harus dikaji secara bersama maupun terpisah. Menurut Willian N. Dunn (2003:24) dalam Budi Winarno (2007: 32-34)tahapan kebijakan publik dapat diklasifikasi menjadi empat tahapan diantaranya :

a. Tahap Agenda Setting

b. Tahap Formulasi Kebijakan

c. Tahap Implementasi Kebijakan

d. Tahap Evaluasi Kebijakan

Dari keempat tahapan tersebut akan menghasilkan ide atau gagasan yang akan ditetapkan sebagai kebijakan unduk dilakukan oleh pemerintah.

\section{Konsep Jabatan Fungsional}

Jabatan adalah suatu lingkungan pekerjaan tetap yang diadakan atau dilakukan guna kepentingan negara (kepentingan umum) E. Utrecht (1994)".Pada hakekatnyaJabatan fungsional merupakan jabatan teknis yang tidak tercantum secara tegas dalam struktur atau bagan organisasi, namun sangat diperlukan dalam pelaksanaan tugas-tugas pokok organisasi pemerintah karena jabatan tersebut didasarkan pada keahlian dan atau keterampilan. Dalam Undang-undang No. 5 tahun 2014 tentang Aparatur Sipil Negara pasal 1 ayat 11 mendefenisikan jabatan fungsional adalah sekelompok jabatan yang berisi fungsi dan tugas berkaitan dengan pelayanan fungsional yang berdasarkan pada keahlian dan keterampilan tertentu. Dengan demikian jabatan fungsional secara sederhana dipahami sebagai jabatan yang tidak tercantum dalam struktur atau bagan organisasi, tetapi dalam rangka pelaksanaan tugas dan fungsinya jabatan tersebut sangat dibutuhkan.

\section{Konsep Jabatan Struktural}

Jabatan Struktural, merupakan jabatan yang secara tegas ada dalam struktur atau 
bagan organisasi pemerintah. Menurut Taliziduhu Ndraha (2002:180), mengatakan bahwa "jabatan struktural adalah jabatan yang menunjukan suatu posisi formal dalam suatu organisasi baik pemrintah maupun suasta”. Peraturan Pemerintah. No 100 tahun 2000 yang diperbaharui dengan Peraturan Pemerintah Nomor 13 Tahun 2012 Tentang Pengangkatan Pegawai Negeri Sipil dalam Jabatan Struktural menjelaskan bahwa "Jabatan struktural adalah suatu kedudukan yang menunjukkan tugas, tanggung jawab, wewenang, dan hak seorang Pegawai Negeri Sipil memimpin suatu satuan organisasi negara".

\section{METODOLOGI PENELITIAN}

Metode yang digunakan adalah metode penelitian kualitatif, denganteknik pengumpulan data yakni observasi, wawancara, studi kepustakaan dan studi dokumen informan dipilih secara purposive yakni teknik penentuan sampel dengan pertimbangan tertentu dimana informan yang dipilih dianggap mengetahui serta mampu memberikan informasi yang sesuai dengan permasalahan penelitian.Informan penelitian berjumlah 12 orang yakni 5 orang anggota Baperjakat, 5 orang Dokter yang dialihkan dalam jabatan struktural dan 5 orang guru yang dialihkan dalam jaabatan stuktural serta 2 orang kepala dinas (Dinas
Pendidikan dan Dinas Kesahatan) Kabupaten Maluku Tenggara Barat.Teknik analisa data dilakukan sesuai dengan yang disampaikan menurut Miles dan Huberman (Moleong, 2005), yakni reduksi data, display data dan verifikasi data, sedangkan dalam melakukan pengecekan keabsahan data dilakukan dengan metode triangulasi (Moleong, 2006:69).Sedangkan teknik pengecekan keabsahan data yaitu Triangulasi yang merupakan cara pengukuran validitas dan memperkuat kredibilitas (derajat kepercayaan) hasil penelitian dengan berbagai pendekatan yang berdeda (Moleng, 2006:69).

\section{PEMBAHASAN}

Pemberlakuan UU No. 5 Tahun 2014 tentang Aparatur Sipil Negara pasal 1 ayat 22 mengatakan pelaksanan tugas pegawai negeri sipil hendaknya didasarkan pada sistem merit yang adalah kebijakan dan manajemen Aparatur Sipil Negara (ASN) yang berdasarkan pada kualifikasi, kompetensi, dan kinerja secara adil dan wajar dengan tanpa membedakan latar belakang politik, ras, warna kulit, agama, asal usul, jenis kelamin, status pernikahan, umur, atau kondisi kecacatan. Sedangkan pasal 2 menjelaskan asas penyelenggaraan yang perlu diperhatikan yakni: (a)kepastian hukum, (b)profesionalitas, 
(c)proporsionalitas,

(d)keterpaduan, (e)delegasi, (f)netralitas, (g)akuntabilitas, (h)efektif dan efisien, (i)keterbukaan, (i)nondiskriminatif, (j)persatuan dan kesatuan, (k)keadilan dan kesetaraan, dan (m)kesejahteraan menjadi acuan dalam meningkatkan kapasitas aparatur sipil degara dalam pemberian pelayanan kepada masyarakat.

Dalam lingkup kepegawaian wewenang pengangkatan, pemindahan, dan pemberhentian pegawai negeri sipil merupakan wewenang resmi Pejabat Pembina Kepegawaian baik di tingkat pusat (Presiden) sampai ke tingkat daerah (Bupati). Sehingga untuk menjamin pengangkatan, pemindahan dan pemberhentian pegawai negeri sipil maka dibentuk Badan Pertimbangan Jabatan Dan Kepangkatan yang disingkat BAPERJAKAT.

\section{PIHAK YANG BERWEWENANG}

Dalam Peraturan Pemerintah RI No. 9

Tahun 2003 yang diubah dengan Peraturan Pemerintah RI No. 63 Tahun 2009 Tentang Wewengan Pengangkatan, Pemindahan dan Pemberhentian Pegawai Negeri Sipil mengatur kewenganan pengangkatan, pemindahan dan pemberhentian pegawai negeri sipil di tingkat daerah menjadi tanggunga jawab penuh atau dengan kata lain pihak yang bertanggung jawab merealisasikannya adalah Pejabat Pembinan Kepegawaian (PPK) daerah dalam hal ini Bupati, dan lewat kewenangan yang dimiliki maka dibentuk tim BAPERJAKAT dan Tim TAK untuk membantu pelaksanaan kewenangan tersebut.

\section{PROSES PENGALIHAN JABATAN}

Formulasi kebijakan (policy formulation) merupakan salah satu tahap dari rangkaian proses pembuatan dan pelaksanaan suatu kebijakan publik yang didalam terdapat tahapan - tahapan yang saling terkait satu sama lain, serta memiliki ketergantungan nilai yang dihasilkan. Tjokroamidjojo dalam Islamy (2000:24) mengatakan bahwa "perumusan (formulasi) kebijakan merupakan proses yang terus menerus dilakukan dan tidak pernah selesai.

Michael. Howlet dan M. Ramesh dalam Subarsono (2005:13 - 14) berpendapat bahwa "formulasi kebijakan (policy formulation) merupakan proses perumusan pilihan - pilihan kebijakan oleh pemerintah dalam mengatasi masalah." Formulasi kebijakan bukanlah tahapan yang berdiri sendiri, melainkan terdiri dari beberapa tahapan yakni tahap perumusan masalah, agenda kebijakan, peramalan (forecasting) dan formulasi kebijakan Ripley (dalam Subarsono 2005:17). Oleh karena 
keterrkaitan tahapan dalam keseluruhan proses formulasi kebijakan memiliki nilai yang sama, maka untuk mengetahui tahapan formulasi kebijakandalam mengalihkan jabatan fungsional ke jabatan struktural maka pada bagian ini, keseluruhan tahapan formulasi kebijakan yang terdiri dari empat tahapan yakni perumusan masalah, agenda setting, peramalan (forecasting) dan formulasi kebijakanakan dibahas secara keseluruhan.

\section{a. Tahapan Perumusan Masalah}

Perumusan masalah merupakan sumber dari kebijakan publik, sehingga diperlukan pemahaman dan identifikasi masalah berdasarkan tujuanya dengan baik dan benar, keberhasilan atau kegagalan dalam perumusan masalah akan mempengaruhi perumusan (formulasi) kebijakan, mempengaruhi keseluruhan proses kebijakan. Setiap masalah dibahas berdasarkan tingkat kebutuhan yang paling dominan, mendesak (Urgen) untuk ditanggulangi namun, tidak semua masalah dalam masyarakat merupkanan masalah publik.

Oleh karena itu diperlukan syarat yang nantinya dipakai sebagai ukuran dalam menentukan apakah suatu masalah merupakan masalah publik atau tidak, selain itu engan syarat-syarat tersebut setiap masalah akan berkompotensi untuk masuk dalam agenda kebijakan. Abdul Wahab (2004:40) mengatakan suatu masalah disebut sebagai masalah publik dengan syarat sebagai berikut :

1. Telah mencapai suatu titik (kritis), sehingga secara praktis tidak dapat diabaikan begitu saja.

2. Telah mencapai tingkat partikularitas tertentu yang dapat menimbulkan dampak (impact) yang bersifat dramatik.

3. Menyangkut emosi tertentu dilihat dari sudut kepentingan orang banyak.

4. Menjangkau dampak yang amat luas.

5. Mempermasalahkan kekuasaan dan keabsahan (legitimasi) dalam masyarakat.

6. Menyangkut suatu persoalan yang fasionable, dimana posisinya sulit untuk dijelaskan tapi mudah dirasakan kehadirannya.

Berdasarkan konsep-konsep tersebut serta hasil penelitian yang dilakukan, maka dalam tahapan perumusan masalah terhadap proses pengalihan jabatan fungsional ke jabatan struktural pada Kabupaten Maluku Tenggara Barat, didasarkan pada beberapa masalah pokok diantaranya :

1. Adanya Kekosongan Pada Jabatan Struktural

Kabupaten Maluku Tenggara Barat merupakan daerah yang baru dimekarkan 
dari kabupaten Maluku Tenggara yakni pada tahun 2000, dan dalam kondisi tersebut terdapat kuang lebih 120 jabatan struktural yang tidak terisi. Dengan demikian dalam upaya untuk mengisi kekosongan tersebut pemerintah daerah mengagendakan masalah ini untuk diangkat dan dibahas dengan tujuan untuk meminimalisir kekosongan pada jabatan struktural yang dihadapi.

2. Adanya Berbagai Masalah Kesehatan Dan Pendidikan

Pada kondisi yang sama terdapat berbagai masalah di bidang kesehatan dan pendidikan, menuntut pemerintah untuk segera menangulanginya. Masalah tersebut dapat dirincikan dalam tabel berikut:

\begin{tabular}{|l|l|c|}
\hline \multicolumn{1}{|c|}{$\begin{array}{c}\text { Masalah } \\
\text { Kesehatan }\end{array}$} & \multicolumn{1}{c|}{$\begin{array}{c}\text { Masalah } \\
\text { Pendidikan }\end{array}$} & Tahun \\
\hline - Keterbatasan & $\bullet$ Keterbatasan & $\bullet 2005$ \\
Sarna dan & sarana dan & - \\
prasarana & prasarana & 2007 \\
- Wabah Malaria & • Buta Huruf & $\bullet 2009$ \\
- Gisi Buruk & • $3 \mathrm{M}$ & $\bullet 2010$ \\
- Tingkat & Membaca, & - \\
Kematian Ibu & menulis dan & 2013 \\
dan Bayi & menghitung) & \\
\hline
\end{tabular}

Dikelolah oleh peneliti, 2015

Dari potensi masalah kesehatan dan pendidikan yang dihadapi tersebut maka pemerintah daerah menetapkan bidang kesehatan dan pendidikan dalam agenda pemerintah.

Selain kedua masalah tersebut, terdapat masalah lain yang juga dihadapi yakni keterbatasan infrastruktus, keterbatasan aparatur (ketenagaan), dan lain sebagainya namun dalam hal pengalihan jabatan fungsional ke jabatan struktural yang didasarkan pada pertimbangan potensi permasalahan yang dihadapi, pemerintah daerah hanya mengagendakan dua masalah diantaranya pengisian jabatan struktural yang mengalami kekosongan dan penanggulangan masalah dibidang kesehatan dan pendidikan. (hasil wawancara,Mei-2015).

\section{b. Tahapan Agenda Kebijakan}

Sejalan dengan pendapat Dunn (2000:132), yang mengatakan bahwa "perumusan kebijakan (policy formulation) merupakan pengembangan terhadap alternatif-alternatif pemecahan masalah". Dengan demikian akan ada beberapa kemungkinan alternatif yang dipilih. Terhadap hal ini Winarno (2002:29) menyatakan bahwa "masing-masing alternatif akan bersaing untuk dipilih sebagai kebijakan dalam rangka memecahkan masalah".

Ripley dikutip dalam Subarsono (2005:8) menambahkan bahwa: "terdapan nilai intelektual sekaligus unsur politik yang terselip dalam tahapan agenda kebijakan, yang menyebabkan alternatif-alternatif kebijakan sulit dipilih secara rasional". 
Selain itu untuk memahami proses dalam tahapan agenda kebijakan ini akan sangat sulit untuk diamati karena faktor legitimasi penguasa.

Dengan berlandaskan dua masalah pokok yang ditetapkan dari sekian permasalahan yang didadapi, yakni kekosongan pada jabatan struktural serta penanggulangan masalah dibidang kesehatan dan pendidikan maka ditentukan beberapa alternatif sebagai pilihan. Adapun alternative-alternatif tersebut ialah:

1. Dilakukan pengisian jabatan struktural melalui rekrutmen yang didasarkan pada kesesuaian dengan syarat jabatan, serta penanggulangan masalahkesehatan dan pendidikan yang dihadapi.

2. Pengisian jabatan struktural dengan menempatkan orang yang paham betul masalah kesehatan dan pendidikan yang dihadapi.

3. Dilakukannya pengisian jabatan strutural dengan mendayagunakan aparatur yang tersedia, dan penanganan masalah kesehatan dan pendidikan yang sedang terjadi.

Berdasarkan alternatif-alternatif yang ditawarkan tersebut, maka alternatif ketiga dipilih sebagai alternatif pemecahan masalah, yang didasarkan pada beberapa pertimbangan yakni:

1. Ketersediaan aparatur yang memenuhi syarat,

2. Urgensi masalah dibidang kesehatan dan pendidikan,

3. Kesesuaian dengan spesifikasi bidang ilmu,

4. Kebutuhan dan kepahaman terhadap masalah.

Pertimbangan tersebut menjadi dasar sekaligus ukuran dalam penentuan alternatif pilihan terbaik, yang akan direkomendasikan untuk dilaksanakan dalam mengatasi permasalahan yang dihadapi secara khusus kebijakan dalam mengalihkan jabatan fungsional ke jabatan struktural (Hasil wawancara, Mei 20015). Dengan berpedoman pada pendekatan konseptual serta realitas di lapangan, maka secara keseluruhan tahapan agenda kebijakan telah dilakukan dengan maksimal, akan tetapi pengkajian dalam proses pemilihan alternatiif yang dilakukan pemerintah daerah tidak dapat mengakomodir dan mempertimbangkan beberapa hal sebagai dasar dalam menentukan kebijakan pengalihan jabatan fungsional ke jabatan struktural diantaranya: 


\section{Pemerintah}

$$
\text { daerah }
$$

tidak

mempertimbangkan ketersediaan aparatur fungsional yang terbatas,

2. Rentan kendali daerah yang sulit dijangkau dalam mengakses pelayanan kesehatan dan pendidikan.

Oleh karena kedua hal ini tidak terakomodir sebagai bahan pertimbangan untuk menentukan pilihan alternatif dalam penanggulangan masalah, maka kebijakan dalam mengalihkan jabatan fungsional ke jabatan structural pada Kab. MTB, justru semakin memperburuk keadaan.Dikatakan demikian karena:

1. Pada awalnya pemerintah daerah secara jelas mengetahui akan keterbatasan aparatur fungsional, tetapi dalam keterbatasan tersebut justru dialihkan, ibarat punya satu kaki malah puntung. Artinya keterbatasan melahirkan keterbatasa.

\section{c. Peramalan (Forecasting)}

Dalam prosese formulasi kebijakan diperlukan peramalan (forecasting) yang bertujuan untuk mengetahui kelemahan dan kelebihan masing-masing alternatif pilihan pemecahan masalah, sehingga dapat diketahui kemungkinan dan peluang kebijakan serta untuk mengetahui kemampuan sumber daya yang akan dipakai
2. Dengan kondisi rentan kendali daerah yang sulit dijangkau tentunya keberadaan aparatur fungsional akan menjamin kualitas pelayanan dibidang pendidikan dan kesehatan. Oleh karena itu aparatur fungsional harus ditempatkan pada unit-unit pelayanan kesehatan dan pendidikan untuk mempermudah akses masyarkat.

Dengan demikian, untuk menentukan alternatif-alternatif pilihan dalam tahapan agenda kebijakan, maka perlu dilakukan pengkajian yang mandalam dan mendetail, dengan memperhatikan nilai intelektual berdasarkan pendekatan konseptual dan realitas daerah sehingga dapat menghasilkan alternatif pilihan yang terbaik diantara berbagai alternatif yang ditawarkan untuk penyelesaian masalah

dalam merealisasikan kebijakan Ripley dalam Subarsono (2005). Tahapan peramalan (forecasting) dilakukan dengan tujuan untuk:

1. Proyeksi : ramalan yang didasarkan pada ekstrapolasi atas kecenderungan masa lalu maupun masa kini ke masa depan.

2. Prediksi :ramalan yang didasarkan pada asumsi teoritik yang tegas, 
dapat berbentuk hukum teoritis, preposisi teoritis, atau analogi.

3. Perkiraan (conjecture): ramalan yang didasarkan pada penilaian yang informati atau penilaian pakai tentang situasi masyarakat masa depan.

Kebijkan pengalihan jabatan fungsional ke jabatan struktural pada Kabupaten Maluku Tenggara Barat, maka alternatif yang dipilih adalah altermatif ketiga yakni: "pengisian jabatan struktural dengan menempatkan orang atau pegawai yang benar-benar paham terhadap masalah kesehatan dan pendidikan yang dihadapi". Alternatif tersebut dipilih oleh pemerintah daerah dengan didasarkan pada beberapa ramalan kemungkinan dari masing-masing alternatif yang tersedia (Hasil wawancara, Mei 2015).

Tabel 9. Ramalan Kemungkinan

\begin{tabular}{|c|c|c|}
\hline $\begin{array}{c}\text { Potensi } \\
\text { Masalah }\end{array}$ & $\begin{array}{c}\text { Pilihan } \\
\text { Alternatif }\end{array}$ & $\begin{array}{c}\text { Ramalan } \\
\text { kemungkinan } \\
\text { (Forecasting) }\end{array}$ \\
\hline $\begin{array}{l}\text { Kekosongan } \\
\text { pada jabatan } \\
\text { struktural dan } \\
\text { adanya } \\
\text { berbagai } \\
\text { masalah } \\
\text { kesehatan dan } \\
\text { pendidikan }\end{array}$ & $\begin{array}{l}\text { Pengisian } \\
\text { jabatan } \\
\text { struktural } \\
\text { melalui } \\
\text { rekrutmen } \\
\text { sesuai syarat } \\
\text { jabatan } \\
\text { serta, } \\
\text { penanggulan } \\
\text { gan masalah } \\
\text { kesehatan } \\
\text { dan } \\
\text { pendidikan. }\end{array}$ & $\begin{array}{l}\text { - } \text { Ketersediaan } \\
\text { aparatur yang } \\
\text { memenuhi } \\
\text { persyaratan } \\
\text { terbatas, } \\
\text { - Keterlambatan } \\
\text { penanganan } \\
\text { masalah karena } \\
\text { keterbatasan } \\
\text { aparatur, } \\
\text { - Kebijakan } \\
\text { program tidak } \\
\text { tepat sasaran. } \\
\end{array}$ \\
\hline
\end{tabular}

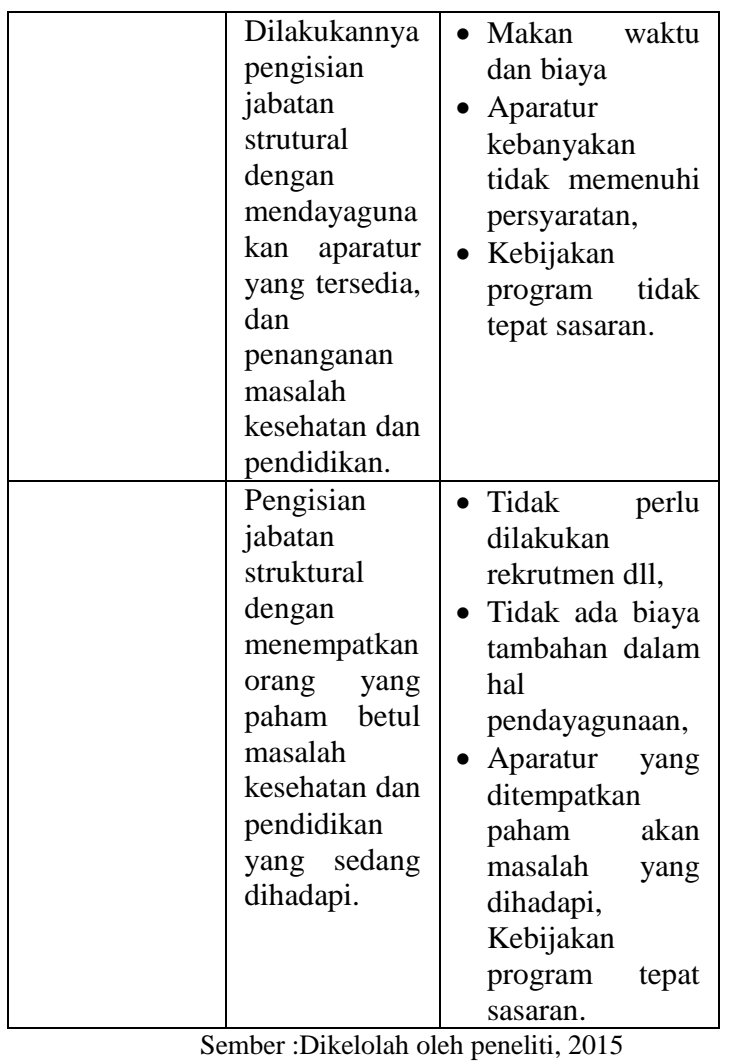

Dengan demikian dapat disimpulkan bahwa dari hasil dalam tahan peramalan (forecasting) tersebut diperoleh gambaran yang akan dijadikan sebagai pedoman perumusan kebijakan yang kondusif dan berpihak kepada kepentingan masyarakat selaku kelompok sasaran dalam pelaksanaan kebijakan teristimewa dalam kebijakan pengalihan jabatan fungsional ke jabatan struktural pada Kabupaten Maluku Tenggara Barat.
b. Tahapan Formulasi Kebijakan
Formulasi kebijakan terdiri dari beberapa tahapan kebijakan mulai dari


perumusan masalah, agenda kebijakan, ramalan kemungkinan sampai pada tahapan formulasi kebijakan, masing - masing memiliki hasil yang saling terkait dikutip dari Ripley dalam Subarsono (2005:15). Sedangkan menurut Fadilah (2001:49-50) dalam formulasi kebijakan hal yang perlu diperhatikan ialah alternatif solusi kebijakan yang dihasilkan harus fleksibel dengan realitas yang terjadi.

Michael Howlet dan M. Ramesh juga berpendapat sebagaimana dikutip dalam Subarsono (2005:13-14) mengatakan bahwa: "Formulasi kebijakan (policy formulation), yaitu proses perumusan pilihan-pilihan kebijakan oleh pemerintah dalam mengatasi masalah". Sedangkan menurut Chief J. O. Udiji seperti yang dikutip dalam Solichin (2002:17) mengatakan bahwa ;

"formulasi kebijakan publik merupakan keseluruhan proses yang menyangkut pengklasifikasian dan pendefenisian masalah, perumusankemungkinan-kemungkinan pemecahan masalah dan penentuan alternatif masalah yang kemudiang diusulkan untuk dibahas dalam agenda pemerintahan”.

Dari pendapat tersebut maka penulis memberikan kesimpulan bahwa: Formulasi kebijakan merupakan tahapan dan proses yang mengarahkan kajiannya pada perumusan masalah berdasarkan realitas, pemilihan alternatif, peramalan untuk memprediksi hasil, yang akan menghasilkan 
solusi penyelesaian dalam bentuk kebijakan.

Dari tahapan demi tahapan dalam proses perumusan kebijakan yang dilakuakan, maka pemerintah daerah Kabupaten Maluku Tenggra Barat, memutuskan untuk memformulasikan sebuah kebijakan

\section{DASAR DAN ATAU ALASAN DALAM MENGALIHKAN JABATAN FUNGSIONAL KE JABATAN STRUKTURAL}

Pemerintah dalam meningkatkan

profesionalisasi aparatur sesuai Peraturan Pemerintah RI No. 41 Tahun 2007 Tentang Organisasi Perangkat Daerah diperhadapkan dengan rightsizing yakni upaya penyederhanaan birokrasi atau disebut juga perampingan yang diarahkan kepada pemerintahan yang miskin struktur tetapi kaya fungsi. Selain itu pemberlakuan UU No. 5 Tahun 2014 Tentang Aparatur Sipil Negara menjadi tantangan baru dimana jabatan struktural setingkat Esalon IV dan $\mathrm{V}$ akan ditiadakan. Oleh karena itu kesiapan aparatur untuk meningkatkan profesionalisme dalam pelaksanaan tugas menjadi hal yang wajib.

Jumlah jabatan struktural semakin sedikit, tetapi aparatur yang ada lebih memilih jabatan struktural ketimbang jabatan fungsional apalagi pada jabata sruktural setingkat esalon II atau, dengan kata lain terjadi perebutan jabatan pada jabatan struktural, sehingga memicu terjadi konflik jabatan antar aparatur.

\section{a. Dasar}

Dengan memperhatikan sistem yang termuat dalam UU No. 5 Tahun 2014 maka yang menjadi dasar dalam penentuan kebijkan pengangkatan, pemindahan dan pemberhentian pegawai negeri sipil ialah Keputusan Kepala BKN No. 43/ KEP/2001 Tentang Standar Kompetensi Jabatan Pegawai Negeri Sipil, yang kemudian akan digunakan untuk menilai kompetensi.

Dengan dasar tersebut maka pemeritah daerah melakukan pengalihan jabatan fungsional ke jabatan struktural, dimana hal ini dilakukan dalam proses kebijakan yang panjang dan rumit. Dengan demikian pemerintah daerah telah memilih, mempertimbangkan dan menetapkan alternatif yang tepat dari beberapa alternatif serta meramalkan berbagai kemungkinan yang dapat terjadi dalam proses kebijakan sehingga dilakukannya pengalihan jabatan fungsional ke jabatan struktural,Dari keseluruhan proses tersebut terdapat maka, pemerintah daerah Kabupaten Maluku Tenggara Barat memiliki berbagai alasan yang kemudian dijadikan sebagai dasar bagi pemerintah daerah dalam mengalihkan jabatan fungsional ke jabatan struktural. 


\section{b. Kebutuhan}

Dalam upaya untuk merealisasikan suatu kebijakan tetunya dibutuhkan berbagai sumber daya sebagai faktor pendukung hal ini kemudian ditegaskan oleh Edward III dalam Widodo (2010:98) mengemukakan bahwa "faktor sumber daya mempunyai peranan penting dalam pelaksanan kebijakan”. Kemudian ia pun menambahkan bahwa "sumber daya tersebut membagi bahwa "sumber daya tersebut meliputi sumber daya manusia, sumber daya anggaran, dan sumber daya peralatan dan sumber daya kewenangan" dikutip dalam Widodo (2010:98) .

Dari konsep ini sumber daya yang menjadi terpenting adalah "manusia". Hal ini juga ditegaskan oleh G. R Terry dalam bukunya The Principle of management yang menempatkan manusia sebagai unsur pertama dalam menajemen. Pendapat lain juga disampaikan oleh beberapa ahli yakni S. P Siangian, Harold Koontz dan O'Donnel yang mengatakan ada enam elemen penting menejemen, namun para ahli ini menempatkan manusia sebagai unsur utama.Dalam kaitannya dengan konsep tersebut maka sumber daya manusia dalam hal ini aparatur selaku pelaksana tugas organisasi pemerintahan sangat menentukan keberhasilan dalam merealisasikan kebijakan lebih khusus dalam mengalihkan jabatan fungsional ke jabatan struktural.Dengan demikian kebijakan pengalihan jabatan fungsional ke jabatan struktural dilakukan berdasarkan kebutuhan daerah, dimana daerah membutuhkan aparatur (sumber daya) untuk ditempatkan dalam jabatan struktural dengan tujuan untuk melaksanakan tugas dan fungsinya berdasarkan tujuan dari masing-masing SKPD.

Dalam wawancara dengan, D.C Makatita S.STP mengatakan bahwa : "Wajar saja jika dokter yang dialihkan dalam jabatan struktural Kepala Dinas Kesehatan karena, dokter sendiri sekaligus yang lebih tahu dan memahami permasalahan kesehatan begitu pun sebaliknya dengan guru, yang juga lebih tahu dan paham masalah pendidikan, dengan demikian akan ada sinergitas program dengan tujuan organisasi karena tingkat pemahaman yang dimiliki” (Wawancara Mei, 2015). Tentunya kebijakan ini murni didasarkan pada kebutuhan daerah dan bukan atas keinginan dari pegawai negeri sipil yang bersangkutan (PNS yang dialihkan) atau hubungan politik, kekeluargaan dan kehendak pimpinan namun dalam prosesnya kebijakan ini tidak disesuaikan dengan kondisi daerah, dimana kondisi aparatur daerah dalan jabatan fungsional juga sangat terbatas, sedangkan kebutuhan aparatur fungsiolnal sangat tinggi yang 
disesuaikan dengan rentan kendali dan jumlah unit pelayanan.

Dengan demikian kebijakan dalam mengalihkan jabatan fungsional ke jabatan strukural dinilai kurang tepat, jika dilihat dari analisi kebutuhan, karena aparatur dalam jabatan fungsional sendiri mengalami keterbatasan yang lebih tinggi jika dibandingkan dengan aparatur dalam jabatan struktural. Pengalihan jabatan fungsional akan lebih tepat jika aparatur fungsional lebih banyak dari kebutuhan.

\section{c. Keterbatasan Sumber Daya Aparatur}

Sebagaimana telah dikatakan dalam uraian sebelumnya bahwa sumber daya aparatur yang berkompetensi akan menghasilkan pelaksanan tugas dan fungsi yang maksimal, dengan demikian Keputusan Kepala BKN No. 43/ KEP/2001 Tentang Standar Kompetensi Jabatan Pegawai Negeri Sipil akam menjadi ukuran dalam penilaian dalam kaitannya dengan kompetensi jagatan.

Dalam wawancara antara peneliti dengan Kepala BKD mengatakan bahwa: "Kabupaten Maluku Tenggara Barat masih saja dihadapkan dengan keterbatasan aparatur yang memenuhi syarat dan kompetensi jabatan untuk menduduki jabatan struktural pada masing - masing SKPD yang belum terisi sehingga dengan keberadaan daerah dan keterbatasan aparatur, maka tidak ada cara lain selain dilakukannya pengalihan jabatan fungsional ke jabatan struktural untuk ditempatkan pada jabatan structural yang belum terisi” (Wawancara Mei, 2015).

Memang diakui bahwa pengalihan jabatan tersebut bukanlah cara yang tepat tetapi tetap harus dilaksanakan mengingat potensi masalah yang terjadi sehingga perlunya pengisisan jabatan sekaligus penanggulangan masalah dibidang kesehatan dan pendidikan. Tetapi bukan berarti pengalihan jabatan tersebut serta merta dilakukan, melainkan sebelum dilakukan pengalihan jabatan tersebut, telah dipersiapkan terlebih dahulu aparatur yang dapat menggantikan posisi fungsional yang akan dialihkan dengan tujuan agar dapat meminimalisir terjadinya keterbatasan sebagai akibat pengalihan jabatan fungsional yang dilakukan (hasil wawancara: Mei 2015).

Peraturan Pemerintah RI. No. 100 Tahun 2000 Tentang Pengangkatan Pegawai Negeri Sipil Dalam Jabatan Struktural, maka Pejabat Pembinan Kepegawaian (PPK) dalam hal ini Bupati perlu mempertimbangkan faktor :

1. Senioritas dalam kepangkatan,

2. Usia PNS yang bersangkutan,

3. Pengalaman yang berhubungan dengan jabatan yang hendak diisi, 
4. Pendidikan dan pelatihan (Diklat) jabatan. Dalam hal ini yang berhasil dalam diklat kepemimpinan yang harus diprioritaskan.

Dalam penentuan jabatan struktural, terdapat persyaratan lain yang juga harus dipenuhi oleh oleh PNS yang. Persyaratan tersebut dapat diklasifikasikan menjadi tiga yaitu:

1. Syarat Adminstratif meliputi spesifikasi pendidikan, dan kepangkatan,

2. Syarat Teknis meliputi penilaian terhadap prestasi kerja,

3. Syarat lainya meliputi moral, sikap, perilaku, dan lainnya.

Dengan memperhatikan persyaratan dan kompetensi tersebut, maka seorang pegawai negeri sipil berhak mengajukan promosi kenaikan jabatan dan pangkat melalui setiap SKPD yang kemudian menjadi tanggung jawab BAPERJAKAT untuk mempertimbangkan hingga memutuskan dan merekomendasikan kepada Pejabat Pembinan Kepegawaian (PPK) yang selanjutnya diputuskan untuk ditetapkan dalam pangkat dan jabatan tertentu. Dari berbagai persyaratan dan kompetensi berdasarkan konsep tersebut, maka terkait dengan kebijakan dalam mengalihkan jabatan fungsional ke jabatan struktural, pemerintah daerah mengakui bahwa aparatur yang tersedia di
Kabupaten Maluku Tenggara Barat belum dapat memenuhi berbagai persyaratan dan dinilai belum layak untuk diangkat dalam jabatan struktural, sehingga pengalihan jabatan fungsional ke jabatan struktural menjadi langkah tepat untuk dilakukan dalam rangka pengisian jabatan struktural (Hasil wawancara, Mei). Dengan demikian penulis dapat menyimpulkan bahwa: "dari konsep dan kenyataan dalam kaitannya dengan kebijakan dalam mengalihkan jabatan fungsinal ke jabatan struktural, pemerintah daerah mengabaikan Peraturan Pemerintah RI No. 100 Tahun 2000 pasal 5 obsien (c) yakni "memiliki kualifikasi dan tingkat pendidikan yang ditentukan". Apapun bentuknya pengalihan jabatan fungsional ke jabatan struktural kurang tepat dan bertentangan dengan regulasi, jika hal ini tetap dipertahankan maka tidak perlu ada regulasi karena, regulasi dibuat untuk dilanggar.

\section{KONSEKWENSI-KONSEKWENSI}

\begin{tabular}{|c|c|c|}
\hline KEBIJAKAN & & DALAM \\
\hline MENGALIHKAN & & JABATAN \\
\hline $\begin{array}{l}\text { FUNGSIONAL } \\
\text { STRUKTURAL }\end{array}$ & $\mathbf{K E}$ & JABATAN \\
\hline
\end{tabular}
Indonesia (KBBI) mengartikan konsekwensi ialah "akibat yang ditanggungkan sebagai hasil dari sebuah tindakan atau perbuatan" dikutip dalam 
pranala

(link):

http://kbbi.web.id/konsekwensi2015.

Dalam kaitan dengan kebijakan pengalihan jabatan fungsional ke jabatan struktural yang dilakukan oleh pemerintah daerah, diakui terdapat konsekwensi konsekwensi yang ditanggung atas kebijakan yang dilakukan. Konsekwensi tersebut dapat diuraikan sebagai berikut:

\section{a. Keterbatasan Aparatut Fungsional}

Pada uraian sebelumnya telah dijabarkan bahwa betapa pentingnya manusia sehingga ditempatkan sebagai urutan teratas dalam segala proses kebijakan konsep ini ditegaskan oleh Edward III dalam Widodo (2010:98) menyatakan bahwa "probably the mostessential resources in implementing policy is staff (sumber daya terpenting didalam pengimplementasian kebijakan ialah para pegawai).Keterbatasan aparatur merupakan fenomena dasar yang memicu diberlakukanya kebijakan dalam mengalihkan jabatan fungsional ke jabatan struktural dan akhirnya melahirkan konsekwensi yang ditanggung baik oleh pemerintah sendiri maupun masyarakat selaku sasaran kebijakan.

Kenyataan membuktikan bahwa aparatur dalam jabatan fungsional pada Kabupaten Maluku Tenggara Barat telah mengalami keterbatasan sejak awalnya (sebelum pengalihan jabatan), akan tetapi pengalihan jabatan fungsional tetap dilakukan. Fenomena ini cukup rumit, namun dalam kondisi ini pemerintah daerah dengan segala upayanya mengusahakan yang terbaik, lewat Bantuan Belajar yang diberikan kepada 58 putra dan putri terbaik daerah untuk melanjutkan studinya pada sekolah kedokteran dengan target 2-3 tahun kedepan dapat kembali untuk mengaplikasikan pengetahuan yang dimiliki bagi masyarakat dan dengan sendirinya keterbatasan ini dapat tertanggulangi dengan baik. (wawancara dengan Kepala Dinas Kesehatan Mei, 2015).

Kenyataan yang lain juga ialah dari jumlah dokter yang dibutuhkan 50 orang, dengan yang tersedia hanya 17 orang, dan dari jumlah ini, 7 orang dialihkan, maka jumlah ini sangat kurang. Keadaan yang sama juga terjadi dibidang pendidikan pada Kabupaten Maluku Tenggara Barat teristimewa pada sekolah-sekolah yang terdapat di kecamatan dan desa, keterbatasan ini mengakibatakan keterlambatan proses belajar mengajar di kelas yang tidak lain disebabkan karena terdapat 119 guru yang dialihkan dalam jabatan struktural.

\section{b. Lemahnya Pelayanan Kesehatan dan Pendidikan}

Pelayanan dipandang sebagai indeks kepuasan yang diterima oleh masyarakat atau konsumen yang memenuhi harapan 
dan kebutuhan. Dalam UU No. 25 tahun 2009 Tentang Pelayanan Publik mendefenisikan pelayanan publik sebagai " kegiatan atau rangkaian kegiatan dalam rangka pemenuhan kebutuhan sesuai dengan peraturan perundang - undangan yang berlaku bagi setiap warga negara dan penduduk atas barang dan jasa atau pelayanan administrasi yang disediakan oleh penyelenggara pelayanan publik".

Dari konsep yang telah dijabarkan tersebut, yang dikaitan dengan kebijakan dalam mengalihkan jabatan fungsional ke jabatan struktural pada Kabupaten Maluku Tenggara Barat, memberikan konsekwensi langsung dalam pelayanan dibidang kesehatan dan pendidikan, sehingga pelayanan yang diberikan manjadi sangat lemah dan sulit dijangkau oleh masyarakat baik dalam segi waktu maupun biaya.

Lemahnya pelayanan ini harus menjadi tanggung jawab pemerintah dengan memperhatikan rentang kendali daerah dan kondisi sosial masyarakat yang belum memadai. Pelayanan kesehatan yang urgen terhitung detik dengan kematian menjadi konsekwensi yang harus ditanggung oleh masyarakat. Dalam kondisi ini masyarakat senantiasa mengaharapkan pelayanan kesehatan dan pendidikan yang mudah dan dapat dijangkau akan tetapi demi memperoleh akses tersebut, masyarakat terpaksa harus mananggung konsekwensi baik waktu, tenaga maupun biaya.

Beta pu paitua sudah sakit malaria di Sera dari satu minggu lalu (Awal bulan Mei) gelombang jadi motor seng bias datang, beta jua seng ada uang, lalu katong baru datang padahal priksa darah begini malaria, terpaksa katong tinggal seng tau anak - anak dong bagaimana, Untung katong datang la periksa lai kalo seng, mungkin antua tambah stenga mati. (Ibu Ete, Mei 2015). Maitua mau melahirkan la katong datang di Puskesmas Lorulung tapi seng ada dokter ka bidan jadi terpaksa katong datang di Saumlaki par bawa maitua, untung cepat kalo seng, tau nanti bagimana. Co begitu ada bidan saja lai ka! Seng ada lai.

Dari hasil wawancara ini jelas masyarakat mengharapkan pelayanan kesehatan yang dapat dijangkau, bukan hanya soal biaya yang akan dikeluarkan tetapi selebihnya pelayanan tersebut tepat dengn kondisi, apalagi pada kondisi yang darurat. Dangan kondisi yang demikian secara jelas kualitas pelayan kesehatan lemah, karena rentan kendali daerah serta keterbatasan petugas kesehatan pada unit - unit pelayanan kesehatan. Memang diakui selain keterbatasan tersebut lemahnya pelayanan kesehatan dan pendidikan juga disebabkan oleh faktor lain yakni keterbatasan saran prasarana namun dalam kondisi yang demikian tentunya kehadiran aparatur pemberi pelayanan sangat diperlukan sehingga 
mengantisipasi keadaan mendesak yang dihadapi oleh masyarakat selaku penerima layanan. Dalam konsep dan kenyataan ini maka dapat disimpulkan kekecewaan dalam masyarakat akan lemahnya pelayanan dibidang kesehatan dan pendidikan, dan dalam kekecewaan ini masyarakat pun tidak mampu menyampaikan secara langsung apa yang dirasakan. Dengan demikian kebijakan dalam mengalihkan jabatan fungsional ke jabatan struktural harus dievaluasikan kembali. Dalam proses evaluasinya pun harus benar - benar mengkaji secara dalam, jangan evaluasi dilakukan secara formalitas saja.

Hal ini menjadi poin penting yang harus diperhatikan oleh pemerintah daerah, bukan hanya kebijakan dilakukan dengan pertimbangan yang bersifat politis dan lain sebagainya saja, namun selebihnya kebijakan yang dilakukan teristimewa kebijakan dalam mengalihknan jabatan fungsional ke jabatan struktural harus memadang realitas dan masyarakat sebagai unsur kajian sehingga kebijakan yang diambil saling bersinergik.

\section{PENUTUP}

\section{Kesimpulan}

Berdasarkan hasi penelitian maka dalam kaitan dengan pengalihan jabatan fungsional ke jabatan struktural dapat disimpulkan sebagai berikut:

1. Pihak Yang Berwewengan

a. BAPERJAKAT dan TAK dalam pelaksanan tugas dan tanggung jawab belum dilakukan dengan baik dan maksimal disebabkan karena Hakprerogative dan Patronage System yang dimiliki oleh PPK lebih dominan dalam penentuan kebijakan.

b. Hasil pertimbangan pihak yang berwewenang sulit direalisasikan karena dipengaruhi oleh otoritas PPK.

2. Tahapan Formulasi Kebijakan

a. Tahapan formulasi kebijakan dalam mengalihkan jabatan fungsional ke jabatan struktural, belum dapat mengakomodir alternatif pemecahan masalah yang singkron dengan realitas masyarakat.

b. Alternatif pilihan dalam tahapan agenda kebijakan belum dapat mengkaji realitas daerah berdasarkan rentan kendali daerah dan kondisi sumber daya aparatur yang tersedia.

3. Pengalihan Jabatan Fungsinal ke Jabatan Struktural

a. Masih terdapat ketidaksesuaian bidang keahlian serta latar belakang pendidikan dengan jabatan yang diembannya sehingga dalam 
pelaksanaan tugas jabatannya menjadi tidak efektif dan efisien.

\section{SARAN}

Dari uraian kesimpulan tersebut maka terdapat beberapa saran yang perlu dipertimbangkan oleh pihak yang berwewenang, diantaranya:

1. Kepada Pihak yang berwewenang.

a. Perlu dilakukanya fungsi control yang maksimal dari pejabat yang berwewenang, sehingga meminimalisir penggunaan hak prerogative atau hak istimewa serta Patronage System dalam proses penentuan kebijakan.

b. Pihak yang berwewenang dalam memberikan berbagai pertimbangan harus memperhatikan objektifitas terhadap penentuan jabatan dan kepangkatan.

2. Pemerintah Daerah perlu mengkaji ulang setiap tahapan kebijakan secara lebih detail sehingga dapat diketahui konsekwensi untuk dijadikan sebagai pedoman dalam kebijakan baru dengan sistem tambal sulam.

3. Pemerintah daerah perlu melakukan pemberdayaan dalam tiga bentuk kegiatan yakni pendidikan, pelatihan dan pendampingan bagi aparatur yang belum memenuhi persyaratan untuk ditempatkan dalam jabatan struktural.
4. Perlu dilakukannya rekrutmen apatarur berdasarkan kualifikasi pendidikan berdasarkan analisis kebutuhan di bidang kesehatan dan pendidikan.

5. Aparatur fungsional yang telah dialihkan sebelumnya perlu difungsionalisasikan kembali dalam tugas yang sesuai dengan spesifikasi keahlian dan ketrampilan yang dimiliki. 


\section{DAFTAR PUSTAKA}

Arikunto Suharsimi, Metodelogi Penelitian, Bina Aksara, Yogyakarta: 2006.

Alaslan, Amtai. 2021. Formulasi Kebijakan Publik: Studi Relokasi Pasar. Banyumas: CV. Pena Persada

Alaslan, Amtai (2021). Kemampuan Pemerintah Desa Dan Pelaksanaan Tugas Administrasi Pemerintahan. Jurnal OTONOMI Ilmu Administrasi Vol. 9. No. 17

Barata Atep, Dasar - Dasar Pelayanan Prima, Elex Media Komputindo, Jakarta: 2004.

Islamy Irfan,Prinsip-prinsip Perumusan Kebijaksanan Negara,Bumi Aksara, Jakarta: 2000

James E. Anderson, Public Policy Making, Holt Rinchard \& Winston Chapter,New York:1979.

Keputusan Kepala BKN No. 12 Tahun 2001 Tentang Ketentuan Pelaksanaan PPRI. No. 100 Tahun 2000 TentangPengangkatan Pegawai Negeri Sipil dalam jabatan Struktural.

Leo Agustino, Konsep Dasar Kebijakan Publik, Alfabeta,Bandung: 2012.

Lewis Carol dan Stuart Gilman, The Thics Challenge In Public Service, Jossey Bass, San Vransisco: 2005

Lexy J. Maleong,Metodologi Penelitian Kualitatif,Remaja Rosdakarya Offset, Bandung: 2008.

Makmur,Pemberdayaan Aparatur Pemerintah dalam Masyarakat Jurnal Ilmiah Good Governance Vol. 2, STIA - LAN, Jakarta: 2003.

MTB dalam Angka Tahun 2014.
Putra Fadillah, Kebijakan Tidak Untuk Publik,Resist Book, Yogyakarta: 2005.

Riant Nugroho, Kebijakan Publik Formulasi Implementasi dan Evaluasi,Gramedia,Jakarta: 2004.

Subarsono. Ab, Analisis Kebijakan Publik Konsep Teori dan Aplikasi, Pustaka Pelajar, Yogyakarta: 2005.

Sugiyono, Memahami Penelitian Kualitatif, Alfabeta, Bandung: 2008.

Thomas R. Dye, Understanding Public Policy,(New Jersey: Pearson Education Inc: 2005).

Umar Husein, Riset Sumber daya manusia dalam organisasi, Jakarta: 2000.

Undang - Undang No. 32 Tahun 2004 Tentang Pemerintahan Daerah.

Undang - Undang No. 5 Tahun 2014 Tentang Aparatur Sipil Negara.

Wayne Parsons,Public policy Pengantar Teori dan Praktik Analisis Kebijakan,Kencana. Jakarta: 2011.

William N. Dunn,Pengantar Analisis Kebijakan Publik, Gadjah Mada University Press, Yogyakarta: 2003. 